\title{
AKTIVITAS ANTIOKSIDAN EKSTRAK ETANOL DAUN BUAS-BUAS (Premna cordifolia Linn.) TERHADAP GAMBARAN HISTOPATOLOGI PARU TIKUS (Rattus norvegicus) WISTAR JANTAN PASCA PAPARAN ASAP ROKOK
}

\author{
Kristina Lusty Tohomi*, Iswahyudi, Sri Wahdaningsih \\ Program Studi Farmasi, Fakultas Kedokteran, Universitas Tanjungpura, Pontianak \\ *email : lusty_kristina@yahoo.com
}

\begin{abstract}
Cigarette smoke is one of free radical source that can cause oxidative stress, emphysema, and inflamation on lung. Leaves of Premna cordifolia Linn. is one of antioxidant that can neutralize the free radical in body. The purpose of the research is to find the antioxidant activity of Premna cordifolia leaves in reducing lung's damage and to find the effective dose that can reduce lung's damage after exposure of cigarette smoke. Dried leaves of Premna cordifolia are maserated with ethanol 70\%. Rats are divided into five groups, Group without treatment (CMC control), group that exposed to smoke, three groups that treated with 200 (P1), 400 (P2), and 600 $\mathrm{mg} / \mathrm{kgBW}$ (P3) of ethanolic extract of Premna cordifolia leaves after smoke exposure, and one group that treated with $18 \mathrm{mg} / \mathrm{kgBW}$ of vitamin $E$ as positive control after smoke exposure. All groups were treated with three cigarette without filter for 14 days. All rat were terminated on the fifteent day. Right lung were collected and subjected to necropsy and stained with Hematoksilin-Eosin. The result show that all doses of ethanolic extract of Premna cordifolia reduce lung damage in enlarge alveolar, thickening of alveolar's wall, and infiltration of inflmation cells in rats. The effective dose is $600 \mathrm{mg} / \mathrm{kgbw}$ because the potential of Premna cordifolia leaves extract was same with the potential of positive contol in reducing the lung damage.
\end{abstract}

Keywords: Antioxidant, Premna cordifolia, Lung histopathology, Cigarette smoke

\begin{abstract}
ABSTRAK
Asap rokok merupakan salah satu sumber radikal bebas yang dapat menyebabkan stress oksidatif, emfisema dan peradangan paru. Daun buas-buas (Premna cordifolia Linn.) merupakan salah satu antioksidan yang dapat menetralisir keberadaan radikal bebas dalam tubuh. Tujuan dari penelitian ini adalah untuk mengetahui aktivitas antioksidan daun buasbuas dalam menurunkan derajat kerusakan paru pada tikus pasca paparan asap rokok dan dosis efektif daun buas-buas yang dapat menurunkan derajat kerusakan paru tikus akibat asap rokok. Simplisia daun buas-buas dimaserasi dengan etanol 70\%. Tikus dibagi menjadi 5 perlakuan, yaitu kelompok yang hanya diberi suspensi CMC (kontrol CMC), kelompok yang hanya diberi paparan asap rokok (kontrol negatif), kelompok perlakuan P1, P2, P3 masing-masing diberi paparan asap rokok dan ekstrak etanol daun buas-buas dengan dosis 200, 400, serta dosis $600 \mathrm{mg} / \mathrm{kgBB}$ dan kelompok perlakuan kontrol Positif diberi paparan asap rokok dan suspensi vitamin E dosis $18 \mathrm{mg} / \mathrm{kgBB}$. Semua kelompok diperlakukan setiap hari dengan menggunakan 3 batang rokok tanpa filter selama 14 hari . Kemudian pada hari ke 15 semua tikus diterminasi dan diambil paru sebelah kanan untuk selanjutnya dibuat preparat histopatologi menggunakan pewarnaan Hematoksilin-Eosin. Hasil penelitian menunjukkan bahwa ekstrak etanol daun buas-buas dapat menurunkan tingkat kerusakan paru-paru pada pelebaran lumen alveolus, penebalan dinding alveolus dan
\end{abstract}


infiltrasi sel radang pada tikus yang terpapar asap rokok. Dosis ekstrak etanol daun buasbuas dosis $600 \mathrm{mg} / \mathrm{kgBB}$ merupakan dosis efektif untuk menurunkan tingkat kerusakan paru-paru hingga tidak berbeda signifikan $(p>0,05)$ dibandingkan dengan kontrol positif.

Kata kunci: Premna cordifolia, Antioksidan, Histopatologi paru, Asap rokok

\section{PENDAHULUAN}

Merokok memberikan implikasi terhadap berbagai faktor utama resiko penyakit, seperti misalnya penyakit paru obstruktif kronik, emphisema dan berbagai penyakit jantung. Prevalensi perokok di Indonesia adalah $69 \%$ pria dan $4 \%$ wanita. Merokok diestimasikan menyebabkan $90 \%$ kanker paru-paru pada pria dan sekitar $70 \%$ pada wanita. Indonesia menduduki peringkat ketiga jumlah perokok terbanyak di dunia dengan jumlah sekitar 141 juta orang, dengan kenaikan konsumsi rokok tertinggi di dunia (WHO, 2013).

Rokok merupakan salah satu polutan berupa gas yang mengandung berbagai bahan kimia antara lain nikotin, karbon monoksida, tar dan eugenol (dalam rokok kretek). Asap rokok yang merupakan sumber radikal bebas dapat mempengaruhi metabolisme makrofag, dengan cara mengaktifkan makrofag untuk melepaskan sel tersebut akan menyebabkan dilepaskannya faktor kemotatik neutrofil, seperti leukorien B4 dan interleukin 8. Faktor-faktor tersebut akan merangsang neutrofil melepaskan protease yang akan merusak jaringan ikat parenkim paru sehingga timbul kerusakan dinding alveolar dan hipersekresi mukus. Kerusakan paru yang terjadi akibat asap rokok berupa terjadinya pelebaran lumen alveolus, penebalan dinding alveolus, dan peradangan alveoulus yang ditandai degan meningkatnya jumlah leukosit pada alveolus (Muhammad Ismiyati, 2009, dan Dietrich, dkk., 2003).

Antioksidan merupakan senyawa yang memiliki kemampuan untuk menetralisir radikal dan mencengah kerusakan pada paru.Salah satu tumbuhan yang dapat berfungsi sebagai antioksidan adalah daun buas-buas (Premna cordifolia Linn.). Tanaman buas-buas memiliki banyak manfaat yaitu sebagai obat asma, hepatoprotektif dan antitumor. Masyarakat umumnya menggunakan daun buas-buas sebagai bumbu masakan (Suhartono, dkk., 2007, Büyükbas, dkk., 2008, dan Vadivu R, dkk., 2008). Berdasarkan penelitian sebelumnya ekstrak metanol daun buas-buas (Premna cordifolia) mempunyai aktivitas antioksidan yang sangat aktif dengan $\mathrm{IC}_{50}$ sebesar 31,91 $\pm 0,43 \mu \mathrm{g} / \mathrm{mL}$. Daun buasbuas mengandung fenolik, flavonoid, flanonol glikosida, alkaloid dan steroid Mahmud, dkk., 2012, Selvam Thamizh, dkk., 2010, dan Bakar, dkk., 2010).

Penelitian tersebut menjadi dasar dilakukannya pengujian aktivitas antioksidan ekstrak daun buas-buas pada tikus jantan yang terpapar asap rokok secara in vivo. Pengujian ini dilakukan dengan mengukur derajat kerusakan histopatologis paru-paru tikus wistar jantan yang terpapar asap rokok setelah pemberian ekstrak etanol daun buas-buas. Pengamatan histopatologi paru yang dilakukan meliputi pengukuran derajat kerusakan berupa pelebaran lumen alveoli, penebalan dinding alveoli dan infiltrasi sel radang. Hasil dari pengamatan ini diberi skor berdasarkan tingkat kerusakan masing-masing parameter.

\section{METODE PENELITIAN}

Alat

Alat yang digunakan pada penelitian ini adalah timbangan analitik (Precisa), blender simplisia (IlinQi FZ-10), waterbath (Memmert WNB 22), oven (Memmert UP400), desikator, peralatan bedah, smoking chamber berukuran $38,5 \times 28,5 \times 22,5 \mathrm{~cm}$. 


\section{Bahan}

Bahan yang digunakan pada penelitian ini adalah daun buas-buas, etanol 70\%, serbuk magnesium (Merck®), larutan $\mathrm{HCl} 2 \mathrm{~N}$, larutan $\mathrm{HCl}$ pekat, larutan $\mathrm{FeCl}_{3} 1 \%$, pereaksi Dragendorff, pereaksi Meyer, perekasi Wagner, larutan $\mathrm{H}_{2} \mathrm{SO}_{4} \quad 2 \mathrm{~N}$, larutan $\mathrm{H}_{2} \mathrm{SO}_{4}$ pekat, asam asetat glasial, vitamin E, Carboxy Methyl Cellulose (CMC), aquades, aluminium foil, kertas saring.

\section{Hewan Uji}

Hewan uji yang digunakan dalam penelitian ini adalah tikus putih (Rattus norvegicus) galur wistar jantan. Sampel diperoleh secara acak yang memenuhi kriteria inklusi yaitu tikus putih wistar jantan, umur $2-3$ bulan, berat badan 100- 200 gram, dan tidak cacat secara anatomi. Sedangkan kriteria eksklusinya adalah pada masa adaptasitikus yang tampak sakit secara fisiologis dan terdapat penurunan berat badan yang drastis.

\section{Tahap Penelitian}

\section{Determinasi Tanaman}

\begin{tabular}{lrr}
\multicolumn{2}{c}{ Tanaman } & buas-buas yang \\
digunakan di & determinasi & di
\end{tabular} Laboratorium Biologi Fakultas Matematika dan Ilmu Pengetahuan Alam Universitas Tanjungpura dengan menyerahkan sampel berupa tanaman utuh dari daun, batang, bunga dan buah

\section{Pengambilan dan Pengolahan Sampel}

Daun buas-buas diambil dari Desa Rasau Jaya 2, Kecamatan Rasau Jaya, Kabupaten Kubu Raya, Provinsi Kalimantan Barat Daun buas-buas yang telah dikumpulkan, disortasi basah, dicuci. Kemudian daun dikeringkan dibawah sinar matahari secara tidak langsung, daun yang telah kering dilakukan pengubahan bentuk dengan menggunakan blender simplisia. simplisia disimpan dalam wadah kering dan tertutup rapat.

\section{Pembuatan Ekstrak}

Metode ekstraksi yang digunakan dalam penelitian ini adalah ekstraksi maserasi. Simplisia daun buas-buas sebanyak $300 \mathrm{~g}$ direndam dengan pelarut etanol $70 \%$, dilakukan pergantian pelarut setiap $1 \times 24$ jam dan pengadukan sesering mungkin. Kemudian ekstrak etanol tersebut dipekatkan menggunakan rotary evaporator dan waterbath hingga diperoleh ekstrak kental.

\section{Penetapan Susut Pengeringan}

Ekstrak ditimbang sebanyak 2 gram dan dimasukkan ke dalam botol timbang dangkal bertutup yang sebelumnya telah dipanaskan pada suhu $105^{\circ} \mathrm{C}$ selama 30 menit dan telah ditara. Sebelum ditimbang ekstrak diratakan dalam botol timbang, dengan menggoyangkan botol. Kemudian dimasukkan ke dalam ruang pengering, dibuka tutupnya. dikeringkan pada suhu $105^{\circ} \mathrm{C}$ hingga bobot tetap. Sebelum setiap pengeringan, dibiarkan botol dalam keadaan tertutup mendingin dalam desikator hingga suhu kamar (Departemen Kesehatan Republik Indonesia, 2000).

\section{Skrining Fitokima}

\section{Pemeriksaan Alkaloid}

Larutan ekstrak ditambahkan dengan $1 \mathrm{~mL}$ asam sulfat $2 \mathrm{~N}$ dan dikocok. Ditambahkan $1 \mathrm{~mL}$ kloroform, dikocok hingga terbentuk 2 lapisan. Lapisan atas yang merupakan lapisan asam diambil menggunakan pipet tetes dan ditambahkan $1 \mathrm{~mL}$ ammonia. Kemudia larutan dibagi menjdai tiga tabung, tabung A ditambahkan 3 tetes pereaksi Dragendroff, tabung B ditambahkan 3 tetes perekasi Mayer dan tabung $\mathrm{C}$ ditambahkan 3 tetes perekasi Wagner. Hasil positif alkaloid ditandai dengan adanya endapan warna putih pada tabung A dan adanya endapan merah bata pada tabung B dan C (Raaman, 2006). 


\section{Pemeriksaan Flavonoid}

Larutan ekstrak sebanyak $1 \mathrm{~mL}$ ditambah dengan sedikit serbuk magnesium sebanyak 1 gram dan larutan $\mathrm{HCl}$ pekat.Perubahan warna larutan menjadi warna merah menandakan adanya flavonoid (Robinson, 1983).

\section{Pemeriksaan Steroid dan Triterpenoid}

Ekstrak sampel sebanyak $1 \mathrm{ml}$ ditambahkan dengan $1 \mathrm{~mL}$ pereaksi Lieberman- Burchard $\left(\mathrm{CH}_{3} \mathrm{COOH}\right.$ glasial dan larutan $\mathrm{H}_{2} \mathrm{SO}_{4}$ pekat). Warna berubah menjadi merah yang menunjukkan adanya senyawa terpenoid dan warna berubah menjadi biru yang menunjukkan adanya senyawa steroid (Kristanti, dkk., 2008).

\section{Pemerikasaan Tanin}

Ekstrak sampel sebanyak $1 \mathrm{~mL}$ ditambahkan $1 \mathrm{~mL}$ larutan gelatin $1 \%$ dan diikuti larutan $\mathrm{NaCl} 10 \%$. Hasil positif ditandai dengan terbentuknya endapan putih (Raaman, 2006).

\section{Pemeriksaan Fenol}

Ekstrak sampel sebanyak $1 \mathrm{~mL}$ ditambahkan 3 tetes larutan $\mathrm{FeCl}_{3} 5 \%$. Hasil positif yaitu timbul warna biru kehitaman (Raaman, 2006).

\section{Pemeriksaan Saponin}

Ekstrak sampel sebanyak $2 \mathrm{~mL}$ dimasukkan ke dalam tabung reaksi, lalu ditambahkan dengan air dan dikocok dengan kuat selama 15 menit. Hasil positif ditunjukkan dengan terbentuknya busa dengan tinggi $2 \mathrm{~cm}$ (Raaman, 2006).

\section{Pengujian Aktivitas Antiokisdan}

\section{Pemaparan Asap Rokok}

Rokok yang digunakan adalah rokok kretek tanpa filter. Semua tikus diberi paparan asap. Proses pemaparan dilakukan dalam smoking chamber. Proses pemaparan dilakukan setiap pagi menggunakan 3 batang rokok. Pemaparan dilakukan selama 14 hari didalam smoking chamber yang terbuat dari plastik ukuran $38,5 \times 28,5 \times 22,5 \mathrm{~cm}$ dilengkapi dengan ventilasi, dua buah air pump dan tempat pembakaran rokok. Satu jam setelah pemaparan asap rokok, tikus diberi ektstrak etanol daun buasbuas sesuai variasi dosis.

\section{Perlakuan Hewan Percobaan}

Seluruh hewan percobaan diadaptasikan selama tujuh hari. Tikus yang diadaptasi akan diberikan makan dan minum secukupnya. Kemudian hewan percobaan dipilih secara acak dibagi menjadi enam kelompok. Kelompok A merupakan kelompok normal tanpa paparan asap rokok dan hanya diberi suspensi CMC $1 \%$ Kelompok B adalah kelompok kontrol postif yang diberikan paparan asap rokok dan vitamin E. Kelompok $\mathrm{C}$ adalah kelompok kontrol negatif yang hanya diberikan paparan asap rokok dan suspensi CMC 1\%. Kelompok D, E dan F adalah kelompok perlakuan yang diberikan paparan asap rokok dan ektrak etanol daun buas-buas dengan dosis 200 , 400 dan 600 mg/kg BB.

\section{Pengamatan Histopalogi Paru}

Preparat diamati dibawah mikroskop dalam 5 lapangan pandang, yaitu pada keempat sudut dan bagian tengah preparat, dengan perbesaran $100 \times$ dan 400x. Sasaran yang dibaca adalah persentase pelebaran lumen alveolus, penebalan dinding alveolus, infiltrasi sel radang dengan kriteria sebagai berikut:

a. Skoring pelebaran lumen dan penebalan dinding

SKOR 0 : tidak ada perubahan histologis

SKOR 1 : terjadi kerusakan pada kurang dari sepertiga lapang pandang

SKOR 2 : terjadi kerusakan pada sepertiga hingga duapertiga lapang pandang 
SKOR 3 : terjadi kerusakan pada lebih dari duapertiga lapang pandang

(Lenzatti Manuella, dkk., 2011, Nurliani Anni, dkk., 2012)

b. Skoring infiltrasi sel radang

SKOR 0 : tidak ada perubahan histologis

SKOR 1 : infiltrasi sel radang pada kurang dari sepertiga lapang pandang

SKOR 2 : infiltrasi sel radang kerusakan pada sepertiga hingga duapertiga lapang pandang

SKOR 3 : infiltrasi sel radang pada lebih dari duapertiga lapang pandang.

(Lenzatti Manuella, dkk., 2011, Nurliani Anni, dkk., 2012)

\section{Analisis Data}

Data kuantitatif yang diperoleh dianalisis dengan program analisis statistik. Data kerusakan paru diolah dengan uji Shapiro Wilk untuk uji normalitas data. Uji homogenitas dilakukan menggunakan uji Homogeneity of Variance Test. Data yang didapat tidak terdistribusi dan tidak homogen, maka selanjutnya data dianalisis menggunakan uji nonparametrik yaitu uji KruskalWallis untuk melihat ada atau tidaknya perbedaan pada kelompok percobaan. Jika terdapat perbedaan, maka minimum harus terdapat satu kelompok yang berbeda dari kelompok lain. Kemudian dilanjutkan dengan melakukan analisis post hoc untuk mengetahui pasangan kelompok mana yang mempunyai perbedaan signifikan dari semua kelompok dengan menggunakan uji Mann Whitney.

\section{HASIL DAN PEMBAHASAN}

\section{Ekstraksi}

Metode ekstraksi daun buas-buas dalam penelitiaan ini menggunakan metode maserasi dengan pelarut etanol $70 \%$. Hasil ekstrak etanol daun buas-buas yang diperoleh sebesar 88 gram dengan nilai rendemen $29,33 \%$.

\section{Penetapan Susut Pengeringan}

Hasil penetapan susut pengeringan ekstrak etanol daun buas-buas adalah $14,523 \%$. Hasil ini membuktikan bahwa ekstrak merupakan ekstrak kental karena termasuk dalam rentang ekstrak kental yaitu 5-30\% (Voight, 1995). Ekstrak kental (Extractum spissum) memiliki konsistensi liat dalam keadaan dingin dan tidak dapat dituang.

\section{Skrining Fitokimia}

Tabel 1. Hasil Skrining Fitokimia Ekstrak Etanol Daun Buas-Buas

\begin{tabular}{llc}
\hline No & Pemeriksaan & Hasil \\
\hline 1 & Alkaloid & + \\
2 & Flavonoid & + \\
3 & Triterpenoid dan Steroid & - \\
4 & Tanin & - \\
5 & Fenol & + \\
6 & Saponin & + \\
\hline
\end{tabular}

Keterangan:

$(+)$ positif : mengandung golongan senyawa;

(-) negatif : tidak mengandung golongan senyawa.

Berdasarkan hasil yang diperoleh pada tabel 1, dapat dilihat bahwa pada ekstrak etanol $70 \%$ dari daun buas-buas mengandung senyawa yang tergolong alkaloid, flavonoid, fenol dan saponin. Hal ini sesuai dengan yang terdapat pada literatur yaitu buas-buas mengandung fenolik, flavonoid, dan alkaloid (Bakar, dkk., 2010). 


\section{HISTOPATOLOGI}

Asap rokok akan menyebabkan terjadinya stress oksidatif. Stress oksidatif menyebabkan peroksidasi lipid yang akan menimbulkan kerusakan sel dan inflamasi. Selanjutnya stres oksidatif menyebabkan peroksidasi lipid yang akan menimbulkan kerusakan sel dan inflamasi. Proses inflamasi akan mengaktifkan sel alveolar makrofag sebagai pertahanan pertama, aktivasi sel tersebut akan menyebabkan dilepaskannya faktor kemotatik neutrofil, seperti interleukin 8 dan leukotrien B4 yang merangsang neutrofil melepaskan protease yang dapat merusak jaringan ikat parenkim paru dengan menyebabkan terjadinya elastisitas berlebihan pada paru sehingga timbul kerusakan dinding alveolar dan hipersekresi mukus. Selain itu radikal bebas akan menyebabkan terjadinya inaktivasi $\alpha 1$-anti trypsin yang berperan sebagai anti protease menyebabkan peningkatan protease akibat aktivasi neutrofil dan defisiensi antiprotease. Sehingga terjadi ketidakseimbangan antara protease dengan antiprotese yang terdapat pada jaringan alveolar menyebabkan degradasi jaringan paru (Lenzatti Manuella, dkk., 2011, Nurliani Anni, dkk., 2012, dan Samuel Santos, dkk., 2004). Skema mekanisme kerusakan paru akibat asap rokok dapat silihat pada Gambar 1 .

Parameter kerusakan paru yang diamati adalah pelebaran lumen alveolus, penebalan dinding alveolus dan infiltrasi sel radang. Metode yang digunakan yaitu dengan pemberian skor (skoring) agar dapat mengukur kerusakan yang ditimbulkan asap rokok serta perbaikan yang terjadi berdasarkan keadaan sel dan jaringan. Hasil pembacaan derajat kerusakan paru dan klasifikasi tingkat kerusakan pada masing-masing kelompok perlakuan tersaji dalam Tabel 2.

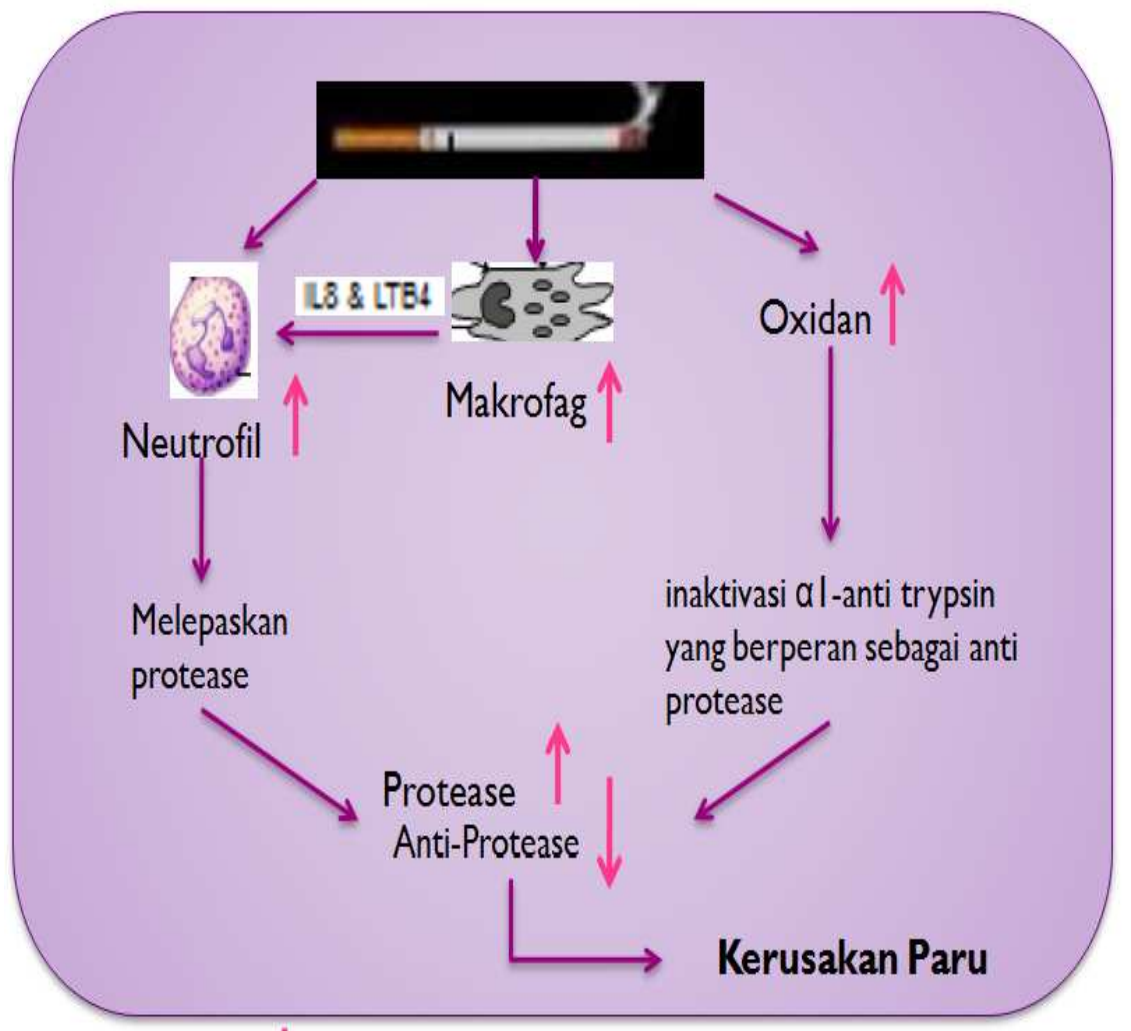

Gambar 1 Skema Mekanismé Kerusakan Paru Akibat Asap Rokok.

$\uparrow=$ meningkat; $\stackrel{\downarrow}{\square}=$ menurun. 
Tabel 2. Hasil Pengamatan Histopatologi Paru

\begin{tabular}{ccc}
\hline Perlakuan & Presentasi KerusakanParu (Mean \pm SD) & Tingkat Kerusakan \\
\hline Normal & $40,15 \pm 3,10$ & Sedang \\
Negatif & $91,45 \pm 0,40$ & Berat \\
Dosis 1 & $82,82 \pm 11,57$ & Berat \\
Dosis 2 & $64,40 \pm 5,52$ & Berat \\
Dosis 3 & $42,70 \pm 7,26$ & Sedang \\
Positif & $43,10 \pm 3,96$ & Sedang \\
\hline
\end{tabular}

Pengamatan terhadap kerusakan paru menunjukkan persentase paling tinggi terdapat pada kelompok perlakuan kontrol negatif yaitu 91,450. Secara statistik hasil tersebut berbeda signifikan $(p<0,05)$ dengan kontrol normal. Kelompok kontrol negatif yang hanya diberikan asap rokok tanpa diberikan ekstrak ataupun vitamin $\mathrm{E}$ menunjukkan kerusakan paling tinggi. Hasil ini sesuai dengan literatur bahwa radikal bebas yang berasal asap rokok dapat mengakibatkan terjadinya kerusakan pada paru melalui mekanisme asap rokok menyebabkan terjadinya stress oksidatif yang merusak alveolus paru. Stres oksidatif yang terjadi secera terus menerus mengakibatkan terjadinya penumpukan hasil kerusakan. Parameter derajat kerusakan paru pada pelebaran lumen alveolus menunjukkan adanya emfisema. Emfisema merupakan keadaan paru yang mempunyai kenaikan ukuran lebih dari normal dan adanya destruksi pada dinding alveoli, hal ini karena asap rokok dapat menghambat asetilkolinesterase, sehingga menyebabkan akumulasi asetilkolin pada paru. Akumulasi asetilkolin ini merangsang bronkhus untuk berkonstriksi sehingga terjadi destruksi dinding alveolus yang menyebabkan air trapping yaitu adanya timbunan udara pada satu tempat, sehingga terjadi pelebaran pada lumen alveolus. Terjadinya kerusakan berupa infiltrasi sel radang ditimbulkan karena respon normal proses biokimia internal maupun eksternal yang menghasilkan suatu radikal bebas endogen yang pada akhirnya dapat menimbulkan terjadinya suatu inflamasi yang ditunjukkan dengan adanya leukosit terutama neutrofil pada mikrovaskuler pulmonal dinding alveolus. Adanya penumpukan sel radang pada dinding alveolus menyebabkan terjadinya penebalan pada struktur dinding alveolus (Lenzatti Manuella, dkk., 2011, Nurliani Anni, dkk., 2012, dan Kim, dkk., 2010). Hasil pengamatan histopatologi paru ditunjukkan pada gambar 2 dan 3 . 

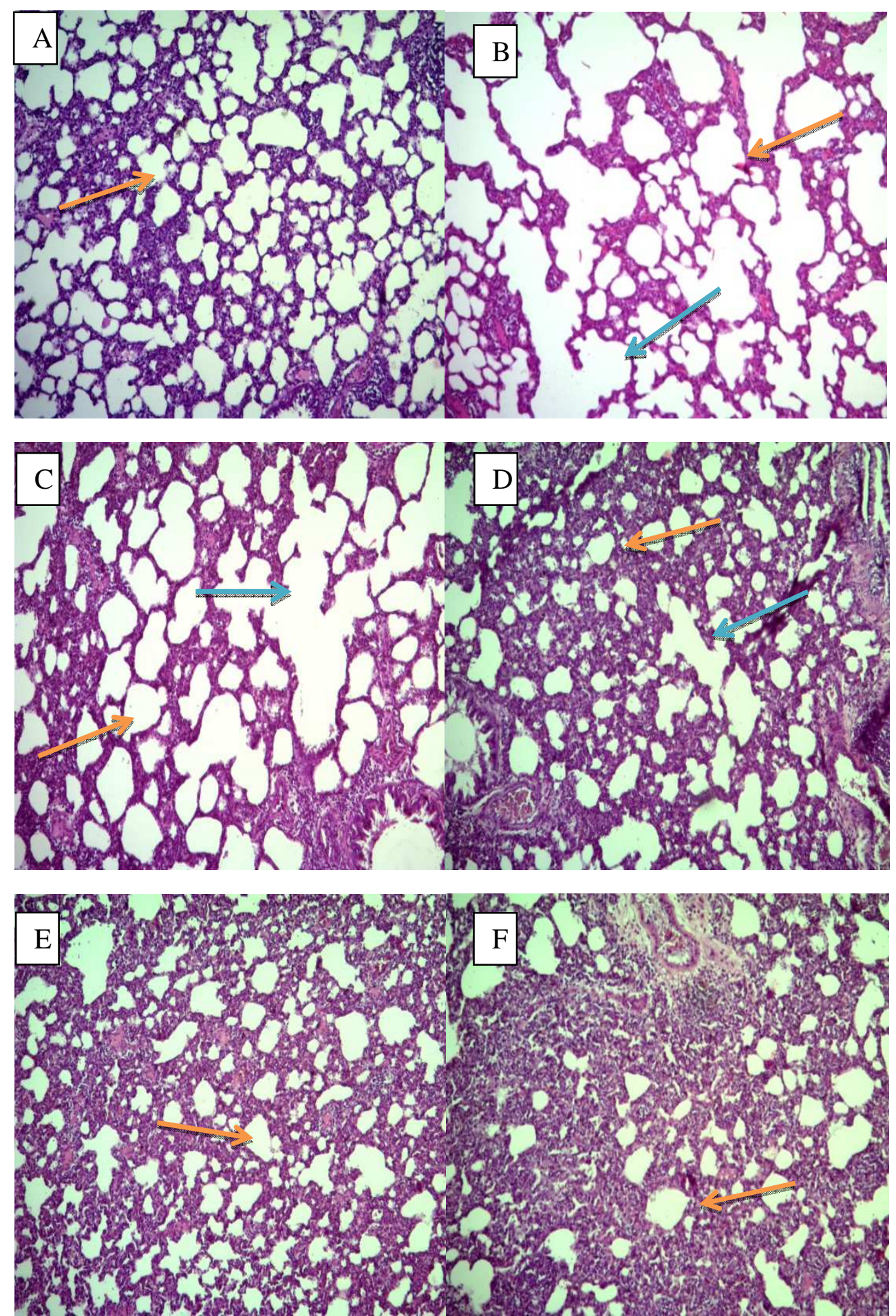

Gambar 1. Gambaran Parameter Pelebaran Lumen Alveolus: A. Kelompok Normal; B. Kelompok Kontrol (-); C. Kelompok Dosis I; D. Kelompok Dosis II; E. Kelompok Dosis III; F. Kelompok kontrol (+). Perbesaran 100×.

Keterangan :

$(\rightarrow)$; Lumen Alveolus Normal

$(\ggg)$; Pelebaran Lumen Alveolus. 

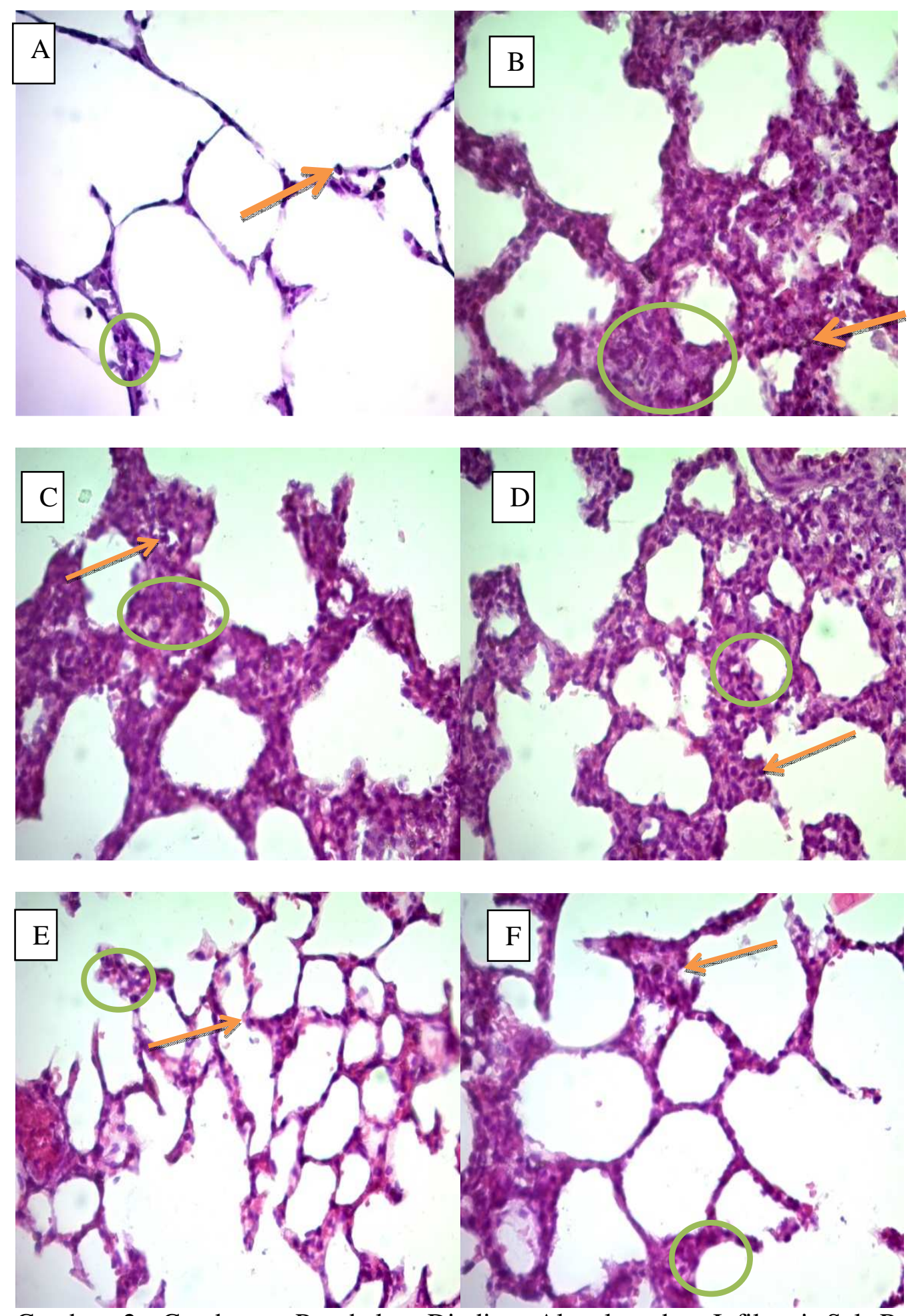

Gambar 2. Gambaran Penebalan Dinding Alveolus dan Infiltrasi Sel Radang : A. Kelompok Normal; B. Kelompok Kontrol (-); C. Kelompok Dosis I; D. Kelompok Dosis II; E. Kelompok Dosis III; F. Kelompok kontrol (+). Perbesaran 400x.

Keterangan :

(O). Penebalan dinding Alveolus;

$(\rightarrow$ infiltrasi sel radang. 
Kelompok perlakuan ekstrak etanol daun buas-buas yang diberikan dosis bertingkat yang terdiri dari dosis I $(200 \mathrm{mg} / \mathrm{kgBB})$, dosis II $(400 \mathrm{mg} / \mathrm{kgBB})$ dan dosis III $(600 \mathrm{mg} / \mathrm{kgBB})$ menunjukkan tingkat kerusakan paru yang semakin menurun seiring dengan meningkatnya dosis pemberian ekstrak etanol daun buas-buas. Namun perlakuan dosis I dan dosis II memiliki tingkat kerusakan yang terberat dibandingkan dengan dosis III. Kelompok kontrol positif yang diberikan vitamin E memiliki tingkat kerusakan yang besar jika dibandingkan dengan kelompok perlakuan dosis III. Hal ini dapat terlihat pada grafik presentase kerusakan paru pada gambar 3 .

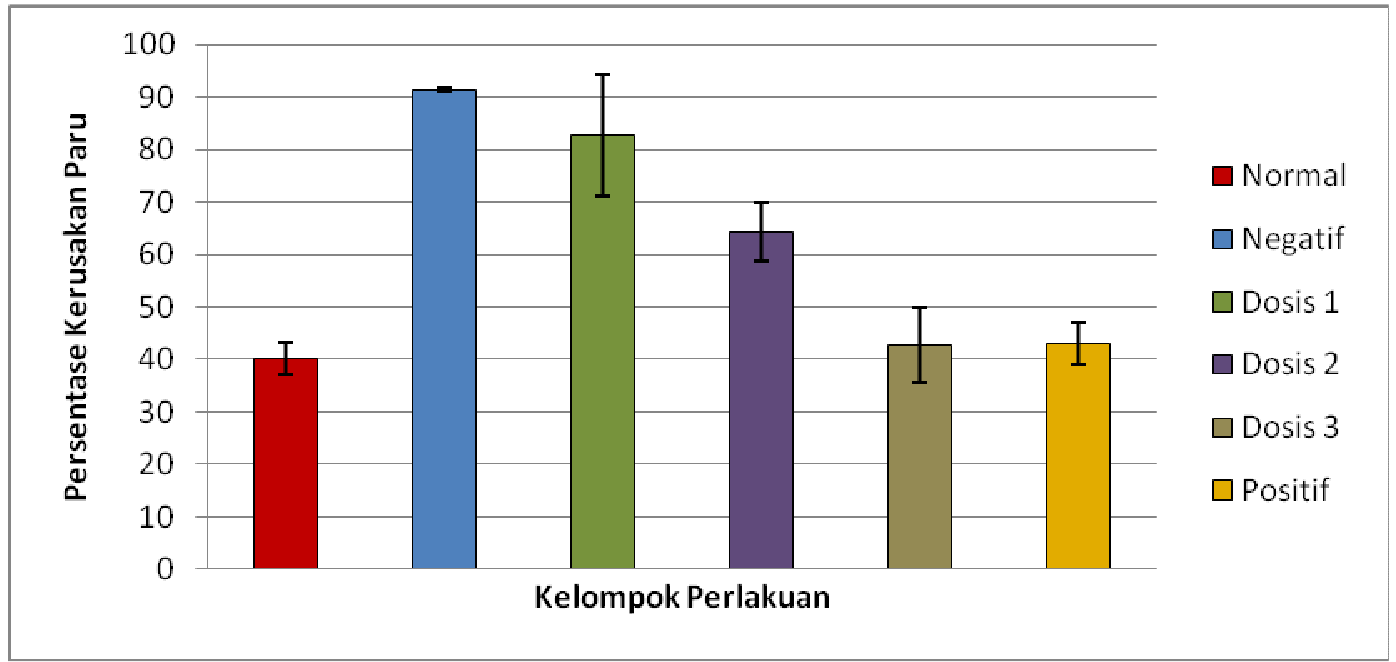

Gambar 3. Presentase Kerusakan Paru

Kelompok kontrol positif berbeda signifikan $(\mathrm{p}<0,05)$ dibandingkan dengan kelompok perlakuan dosis I dan dosis II, dan tidak berbeda signifikan $(\mathrm{p}>0,05)$ dengan perlakuan dosis III dan kelompok normal, namun nilai derajat kerusakan yang dimiliki kontrol positif lebih besar dibanding perlakuan dosis III. Hasil ini menunjukkan bahwa vitamin $\mathrm{E}$ dapat menurunkan derajat kerusakan paru, namun perbaikan yang dihasilkan tidak sebaik yang dihasilkan pada kelompok perlakuan dosis III.

Perlakuan dosis II dan dosis III memiliki perbedaan signifikan $(p<0,05)$ jika dibandingkan dengan kelompok perlakuan kontrol negatif. Hasil ini menunjukkan bahwa pada dosis pemberian ekstrak etanol daun buas-buas dosis dosis I (200mg/kgBB) dan dosis II $(400 \mathrm{mg} / \mathrm{kgBB})$ sudah dapat menurunkan derajat kerusakan histopatologi paru, namun tidak sebaik pada perlakuan dosis III $(600 \mathrm{mg} / \mathrm{kgBB})$ dan vitamin $\mathrm{E}$, hal ini karena dosis I dan dosis II menunjukkan perbedaan signifikan $(\mathrm{p}<0,05)$ jika dibandingan dengan kelompok kontrol normal. Perlakuan dosis III ekstrak etanol daun buas-buas $(600 \mathrm{mg} / \mathrm{kgBB})$ merupakan dosis yang paling baik dalam menurunkan derajat kerusakan histopatologi paru, karena berbeda signifikan $(\mathrm{p}<0,05)$ dibandingkan dengan kelompok kontrol negatif dan tidak berbeda signifikan ( $>0,05)$ dibandingkan dengan kontrol normal. Ekstrak etanol daun buas-buas sebagai antioksidan dalam menurunkan derajat kerusakan paru diduga karena mengandung senyawa alkaloid, fenol, flavonoid dan saponin yang menunjukkan hasil positif pada uji skrining fitokimia. 
Senyawa-senyawa metabolit sekunder ini telah diteliti aktivitasnya sebagai antioksidan. Menurut Abdelmohsen, dkk., (2012) Alkaloid diazepinomicin yang terdapat dalam Micromonospora sp., mempunyai aktivitas sebagai antioksidan berperan sebagai scavenger yaitu melindungi selsel dari adanya radikal bebas yang mampu merusak sel dan sebagai antiprotease dalam menghambat rhodesain and cathepsin L, rhodesain dan cathepsin L ini merupakan enzim yang berperan sebagai biomarker adanya kerusakan sel pada organ. sehingga dari mekasnisme tersebut ekstrak etanol yang mengandung senyawa alkaloid diduga dapat menurunkan derajat kerusakan paru Abdelmohsen, dkk., (2012). Menurut Comalada (2006) menyatakan bahwa senyawa flavonoid dapat berkhasiat sebagai antioksidan melalui aktivitasnya sebagai scavenger, serta menurut Lenzatti (2011) senyawa flavonoid yang terdapat dalam teh berfungsi sebagai inhibitor protease. Sehingga ketika asap rokok masuk kedalam tubuh yang memicu proses inflamasi yang menyebabkan adanya ketidakseimbangan antara antiprotese dengan protease yang terdapat pada jaringan alveolar menyebabkan degradasi jaringan paru. Flavonoid ini akan menghambat kerja dari protease untuk mengelastisitas paru sehingga jaringan paru akan mengalami perbaikan dari adanya pelebaran lumen alveolus. Selain itu flavonoid sebagai antioksidan dalam menurunkan derajat kerusakan paru dapat mengurangi pelepasan sel radang seperti alveolar makrofag dan neutrofil. Menurut Elekofehinti (2012) saponin dalam Solanum anguivi mempunyai aktivitas sebagai antioksidan melalui aktivitasnya sebagai scavenger. Serta menurut NgTB (2014) Saponin dalam kedelai berperan sebagai antioksidan karena memiliki peran sebagai inhibitor protease dalam menghambat pelepasan sitokin seperti
TNF-alpha, IL-1beta, IL-2 dan interferon-gamma.

\section{KESIMPULAN}

Berdasarkan hasil penelitian yang dilakukan dapat disimpulkan bahwa ekstrak etanol daun buas-buas (Premna cordifolia Linn.) dapat menurunkan derajat kerusakan histopatologi paru tikus wistar jantan pasca paparan asap rokok dan Dosis efektif ekstrak etanol daun buas-buas yang dapat menurunkan derajat kerusakan paru tikus wistar jantan akibat paparan asap rokok adalah $600 \mathrm{mg} / \mathrm{kgBB}$.

\section{DAFTAR PUSTAKA}

1. Abdelmohsen Usama Ramadan, Matthias Szesny, Eman Maher Othman, TanjaSchirmeister, Stephanie Grond, Helga Stopper and Ute Hentschel. Antioxidant and AntiProtease Activities of Diazepinomicin from the Sponge-Associated Micromonospora Strain RV115. Mar. Drugs. 2012. ISSN : 1660-3397. 10 : 2208-2221.

2. Bakar, F. A, Mohamed, S, Hamid, A. A, dan Mustafa, R. A. Total Phenolic Compounds, Flavonoids, And Radical Scavenging Activity Of 21 Selected Tropical Plants. Journal of Food Science. Januari-Februari 2010; 75(1): Hal 28-35.

3. Büyükbas S, Kürsat U, Elif D, Kemal B. Oxidarive Stress and Antioxidant Status in Bronchoalveolar Lavage Fluid, Plasma and Erythrocyte of Critically Mixed Ill With Respiratory Failure. Eur J Gen Med. 2008; 5(3):140-146.

4. Comalada M. Inhibition of proinflammatory markers in primary bone marrow-derived mouse macrophages by naturally occurring flavonoids: Analysis of the structure-activity relationship.

Biochemical pharmacology. 2006: (72)1010-1021. 
5. Departemen Kesehatan Republik Indonesia. Parameter Standar Umum Ekstrak Tumbuhan Obat. Jakarta: Departemen Kesehatan Republik Indonesia; 2000. Hal 5, 9-12.

6. Dietrich M, Gladys B, Edward PN, Mark H, Maret GT, Carroll EC, dan Lester P. Smoking and exposure to environmental tobacco smoke decrease some plasma antioxidants and increase tocopherol in vivo after adjusment for dietary Antioxidants intakes. Am J Clin Nutr. 2003; 77:1606.

7. Elekofehinti OO, Adanlawo IG, Saliu JA, Sodehinda SA. Saponins from Solanum anguivi fruits exhibit hypolipidemic potential in Rattus novergicus. Der Pharmacia Lettre. 2012: 4 (3) 811-814.

8. Kim JM, Lee EK, Kim DH, Yu BP,Chung HY. Kaempferol modulates pro-inflammatory NF-kappaB activation by suppressing advanced glycation endproduct-induced NADPH oxidase. The Official Journal of the American Aging Association. 2010; 32(2):197-208.

9. Kristanti AN, Aminah NS, Tanjung M, Kurniadi B. Buku Ajar Fitokimia. Surabaya: Airlangga University Press. 2008. Hal 48-49.

10.Lenzatti Manuella, Alan Lopes, Thiago S. Ferreira, Roberto Soares de Moura, Angela Resende, Luis Cristovao Porto, Samuel Santos Valenc. Mate Tea Ameliorates Emphysema In Cigarette SmokeExposed Mice. Experimental Lung Research. 2011 Juni-Oktober. ISSN: 0190-2148. 246-257.

11.Mahmud ZA, Bachar SC, Qais N. Antioxidant and hepatoprotective activities of ethanolic extracts of leaves of Premna esculenta roxb. against carbon tetrachloride-induced liver damage in rats. $J$ Young Pharmacists. 2012: 4:228-234.
12.Muhammad Ismiyati. Efek Antioksidan Vitamin C terhadap Tikus (Rattus norvegicus) Jantan Akibat Pemaparan Asap Rokok. Tesis. 2009. Sekolah Pascasarjana Institut Pertanian Bogor.

13.NgTB, Cheung Randy CF, Ye X J, Wong Jack $\mathrm{H}$ and Ye $\mathrm{X}$ Y. Protease Inhibitors, Lectins, Antifungal Protein and Saponins in Soybean. www.intechopen.com. Diunduh tanggal 16 Agustus 2014.

14.Nurliani Anni, Santoso Heri Budi, Rusmiati. Efek Antioksidan Ekstrak Bulbus Bawang Dayak (Eleutherine palmifolia) pada Gambaran Histopatologis Paru-paru Tikus yang Dipapar Asap Rokok. Bioscintiae. 2012.9(1): 60-69.

15.Raaman, N. Phytochemical Technique. New Delhi: New India Publishing Agency; 2006. Hal 21-22, 230.

16.Robinson, T. The Organic Constituents of Higher Plants Their Chemistry and Interrelationships. 5th Ed. North Amherst: Cordus Press; 1983.

17. Samuel Santos, Valenc A, Katia Da Hora, Paulo Castro, Vera Gonc, Alves Moraes, La'Is Carvalho, Lu'Is Crist 'OvAo De Moraes Sobrino Porto. Emphysema and Metalloelastase Expression in Mouse Lung Induced by Cigarette Smoke. Toxicologic Pathology. 2004 April. ISSN: 01926233. 32(3) : 351-356.

18.Selvam Thamizh. N, Vengatakrishnan V, Damodar Kumar S, Murugesan. S. Evaluation of tissue level antioxidant activity of Premna serratifolia leaf in paracetamol intoxicated wistar albino rats. International Journal of Pharmacy \& Life Sciences. 2010; 1(2): 86-92. 
19. Suhartono E, Fachir H, Setiawan B. Rokok sebagai sumber radikal bebas dalam Kapita selekta biokimia : Stres oksidatif dasar \& penyakit. Banjarmasin: Pustaka Banua; 2007.Hal 117-8.

20.Vadivu R, Suresh AJ, Girinath K, Kannan PB, Vimala $\mathrm{R}$ dan Kumar NMS. Evaluation of Hepatoprotective and In-vitro Cytotoxic Activity of Leaves of Premna serratifolia Linn. Journal of Scientific Research Publications Department of Pharmacognosy College of Pharmacy Madras Medical College. 2008: 157164.
21.Voight R. Buku Pelajaran Teknologi Farmasi. Yogyakarta: UGM Press; 1995. Hal 561,567-569,577.

22.Worl Health Organization. WHO Report : The Global Tobacco epidemic [Internet]. 2013 [Dikutip 11 Oktober 2013]. Tersedia dari: http://www.who.int/tobacco/surveillan ce/policy/country_profile/idn.pdf 